\title{
Меры повышения инвестиционной привлекательности нефтепоисковых работ
}

\author{
А.В. Соколов, кандидат геолого-минералогических наук, \\ ООО «ПЕТРОГЕКО», Нижневартовск. E-mail: sokolov@petrogeco.ru
}

Статья посвящена актуальной проблеме привлечения частных инвестиций к нефтепоисковым работам. Автор, имеющий многолетний опыт практической деятельности в геологоразведочной компании, рассматривает потенциал увеличения поисковой активности трех основных групп участников российского рынка недропользования - государства, крупных вертикально-интегрированных корпораций и независимых геологоразведочных компаний. По его мнению, наибольшим потенциалом для наращивания поисковой активности обладают независимые компании, однако существующий порядок регулирования восстановления минерально-сырьевой базы не способствует инвестиционной привлекательности поисковых работ. В статье предложены конкретные меры по созданию условий для повышения мотивации независимых инвесторов и привлечения венчурного капитала в нефтеразведку.

Ключевые слова: восстановление минерально-сырьевой базы, геологоразведочные работы, недра, запасы нефти, нефтепоисковые работы, геологическое изучение недр

Ситуация с подготовкой новых запасов нефти в нашей стране стала ухудшаться в 2002 г., после отмены ставки ВМСБ¹. Вероятно, тогда уверенность в неисчерпаемости нефтяных запасов России вообще, и Западной Сибири в особенности, дала повод государству без особой жалости лишить нефтянку адресных средств на геологоразведку. К тому же и эффективность расходования

${ }^{1}$ Налог на воспроизводство минерально-сырьевой базы (ВМСБ) имел разные отраслевые ставки и разную налоговую базу. Так, для золотодобытчиков он составлял 7,8\% от стоимости реализованной продукции; для предприятий, добывающих цветные металлы, $-8,2 \%$; а для нефте- и газодобывающих компаний - $10 \%$ от оборота. При этом $40 \%$ собранных средств должны были поступать в федеральный и территориальные фонды МСБ (по 20\% на каждый уровень), 60\%-оставаться недропользователям для покрытия целевых затрат на геологоразведку. Подробнее см. URL: https://www. kommersant.ru/doc/157918 (дата обращения: 15.08.2018). В настоящее время вместо ВМСБ существует налог на добычу полезных ископаемых (НДПИ), размер ставки которого привязан к мировым ценам на ресурсы. URL: https://studwood.ru/1387188/ finansy/teoreticheskie_aspekty_poryadka_ischisleniya_uplaty_naloga_dobychu_poleznyh iskopaemyh (дата обращения: 15.08.2018). При этом все собранные средства поступают в федеральный и региональные бюджеты. 
средств из фонда ВМСБ часто вызывала нарекания и претензии со стороны регулирующих органов, так как неизрасходованные в течение года целевые ресурсы недропользователи обязаны были вернуть в бюджет, что вынуждало их прибегать к затратному механизму расходования средств. А рост нефтедобычи и мировых цен на нефть в начале 2000-х гг. стал лишним доказательством «правильности» принятого решения. И деньги, которые ранее шли на геологоразведочные работы (ГРР), были использованы для решения других, более неотложных государственных задач.

Таким образом, именно 2002 г. можно считать точкой отсчета, когда государство практически самоустранилось от системного финансирования работ по развитию своей ресурсной базы, переложив все бремя расходов на ГРР на нефтяные компании. Сейчас последствия этого решения очевидны - структура МСБ страны стремительно ухудшается ${ }^{2}$.

Можно ли исправить ситуацию, найдя действенные механизмы стимулирования увеличения вложений в геологоразведку? На наш взгляд - это вполне реально.

Всех игроков на рынке недропользования, которые ведут геологоразведочные работы, условно можно разделить на три класса. Первый - собственно нефтяные компании, которые заинтересованы в поддержании своей нефтедобычи и с этой целью готовы финансировать поисковые работы, главным образом, в радиусе своей производственной инфраструктуры. Второй класс - независимые инвесторы, как правило, стремящиеся занять «свободные» участки недр для последующей продажи или самостоятельной добычи. И наконец, государство, которое на правах собственника продолжает финансирование ГРР, но лишь в отдельных регионах, и в явно недостаточных объемах. Например, бюджет МПР РФ уже долгое время не превышает 30 млрд руб. в год, в то время как совокупные затраты на геологоразведку нефтегазовых компаний ежегодно составляют 300 млрд руб.

Если состав и мотивация действий первого класса инвесторов вполне понятны, «портрет» представителей второго класса еще до конца не ясен. Как правило, независимыми инвесторами выступают бывшие менеджеры нефтегазовых компаний, либо представители (выходцы) финансово-промышленных групп,

\footnotetext{
${ }^{2}$ См. об этом: Шмат В. В. Зачем резать «дойную корову»?! //ЭКО. 2013. № 6. С. 94.
} 
которые рассматривают венчурные инвестиции в нефтепоиск как один из вариантов диверсификации бизнеса. Очень часто промышленная разработка новых месторождений не входит в их стратегические планы, вся активность ограничивается поисками для них подходящего покупателя из числа профильных организаций. Такая бизнес-идея сформировалась благодаря развитию в стране рынка недропользования. А распространенное мнение о том, что выручка от продажи компании с новым открытым месторождением может намного превышать затраты ГРР, лишь подогревает к ней интерес. Благодаря этой легенде, оказались востребованными лицензии на геологическое изучение (ГИ) недр, которые выдаются, по сути, «бесплатно» при соблюдении ряда условий, сроком на пять лет. Так, если в 2004 г., когда появился этот вид недропользования, было выдано восемь лицензий на ГИ, то в 2008 г. и в дальнейшем ежегодно выдавалось более 40 лицензий.

Однако из года в год структура ресурсной базы предлагаемых для геологического изучения участков ухудшается. По мере выбора наиболее перспективных из них возрастает доля участков с высокой степенью поискового риска. Статистика показывает, что большинство открытых в последнее десятилетие месторождений относятся к низкопроницаемым, и как следствие, низкодебитным и обводненным, да еще мелким и мельчайшим по своим размерам. Следует отметить, что и нефтяные компании, работая в пределах своих инфраструктурных производственных кластеров, практически исчерпали свой поисковый потенциал. Увеличение стоимости сейсмических и буровых услуг за последние 18 лет в десять и более раз только усложняет ситуацию-объемы соответствующих работ год от года сокращаются.

Государство попыталось повысить интерес инвесторов к геологоразведочным работам, установив в рамках лицензии на геологическое изучение недр пятилетнюю отсрочку разового платежа за открытие месторождения, но системных проблем воспроизводства запасов нефти устранить таким способом не удалось. Объявленный в конце 2016 г. заявительный принцип получения лицензии на геологическое изучение уже в 2017 г. был тут же, по сути, дезавуирован и обставлен многими условиями и ограничениями. Ожидание отнесения затрат на ГРР 
на уменьшение облагаемой базы при расчете налога на прибыль неоправданно затянулось.

Тем не менее часто обсуждаемая в последнее время идея увеличить финансирование ГРР за счет средств госбюджета (со ссылкой на те времена, когда право собственности на недра и геологоразведка находились в одних государственных руках) кажется неконструктивной. На наш взгляд, оставшиеся в наследство от советского прошлого ресурсная база и поисковый менталитет приведут лишь к открытию новых маргинальных и потому опять невостребованных месторождений. Какой смысл тратить миллиарды рублей на геологоразведку, если открытия не окупят риск? Из-за тотального дефицита бюджетных средств, повышенных рисков и хронической низкой эффективности ГРР участие государства в масштабном финансировании ГРР в ближайшей и среднесрочной перспективе представляется невозможным и нецелесообразным.

Вряд ли следует ждать увеличения объемов высокорисковых нефтепоисковых работ со стороны вертикально-интегрированных корпораций. Только в ХМАО-Югре у них на балансе находится более 4 млрд т запасов нефти категории В2. Очевидно, что в ближайшем будущем основная активность корпораций будет наблюдаться в переводе запасов из категории В2 в В1 в процессе эксплуатационного бурения.

Фактически все надежды по восстановлению минеральноресурсной базы оказываются связаны с третьей группой игроков на рынке недропользования - независимыми инвесторами. Однако практика последнего десятилетия показывает, что даже самые непоколебимые оптимисты уходят из этого сегмента рынка. Почему это происходит?

Во-первых, финансирование поисковых работ идет, как правило, за счет капитала основных владельцев. При этом опыт показывает, что только в единичных случаях (при успешных продажах нефтепоисковых компаний) первоначальным инвесторам удается вернуть вложенные средства с прибылью.

Во-вторых, выдавая свидетельство о факте открытия месторождения в рамках лицензии на геологическое изучение недр, государство признает, что для конкретного участка недр была создана прибавочная стоимость за счет средств независимого инвестора. Однако на капитализацию компании инвестора это 
никак не влияет, поскольку по Конституции РФ недра принадлежат государству, а в рамках пятилетней лицензии на геологическое изучение запрещена любая коммерческая деятельность. Поэтому в течение всего периода геологоразведочных работ стоимость нефтепоисковых компаний имеет «мусорные» значения, что закрывает им доступ к заемным средствам.

«Финальным ударом» по мотивации независимых инвесторов к ведению поисковых работ является необходимость выплаты разового платежа по факту открытия месторождения в рамках лицензии на ГИ. Если новое месторождение окажется достаточно крупным по запасам, размер платежа будет соизмерим, а иногда может даже превысить стоимость поисковых работ за прошедшие пять лет. И такие расходы мало кто из инвесторов может себе позволить.

В то же время отказ от внесения платежа расценивается как нарушение существенных лицензионных условий, что может привести к досрочному отзыву лицензии. Открытое месторождение в таком случае поступает в нераспределенный фонд недр и будет продано на аукционных торгах на общих основаниях (разумеется, по более высокой цене).

Внесение платежа означает, что компания сохраняет за собой право недропользования на открытое месторождение, но уже в ином статусе - нефтедобывающей организации. Однако становиться «нефтяниками» независимые инвесторы, как правило, не хотят. Во-первых, это несколько иная деятельность, требующая других бизнес-подходов и других мощностей. Вовторых, процесс ввода нового месторождения в разработку, как правило, требует многократно больших затрат, чем поисковые работы, и это гораздо более долгосрочные инвестиции. Для сравнения: затраты на поисковые работы (сейсмика + бурение одной скважины) на среднестатистическом участке недр в ХМАО составляют 500 млн руб. А для запуска на разработку среднестатистического месторождения уже требуется не менее 4-5 млрд руб.

Как результат, сложности с привлечением инвестиций приводят к тому, что участки недр, предлагаемые государством для геологического изучения, часто остаются невостребованными.

Еще хуже, когда участки недр разбираются в спекулятивных целях - в расчете на будущую перепродажу юридического лица 
- недропользователя, либо на то, что найдется инвестор для финансирования работ. Очень часто ни того, ни другого сделать не удается, но лишь после истечения пятилетнего срока, если работы так и не были начаты, лицензия на ГИ аннулируется. Такой длительный «простой недр» негативно сказывается на воспроизводстве запасов.

Чтобы стимулировать поисковые работы на нераспределенном фонде недр, необходимо создать условия для увеличения их инвестиционной привлекательности. Потенциальному инвестору должна быть понятна вся «цепочка» создания стоимости: «участок недр - ожидаемый размер открытия и его рентабельность физические объемы работ и время их выполнения - динамика финансирования - возможный покупатель». Для этого, по нашему мнению, распорядителю недр необходимо сделать следующие три шага навстречу независимым инвесторам.

1. Ввести в обиход понятие «Независимая геологоразведочная компания» (НГРК). Этот статус должен присваиваться юридическому лицу, получившему лицензию на геологическое изучение недр, согласно Приказу МПР России от 15.03.2005 № 61 (ред. от 27.01.2014).

2. Отменить для НГРК оплату разового платежа за открытие в рамках лицензии на геологическое изучение при следующих условиях:

- отказ после открытия месторождения от переоформления лицензии на разведку и добычу;

- закрепление исключительного права на продажу открытых запасов за распорядителем недр путем проведения аукциона.

3. Обеспечить распределение средств, полученных от продажи месторождения, между НГРК и государством по заранее известной формуле.

В предложенном сценарии государство, выступая гарантом и посредником, дает возможность независимым инвесторам вернуть свои затраты, при этом собственные риски сводит к нулю, а по итогам аукциона может получить доход, сопоставимый с размерами нынешних разовых платежей. В свою очередь независимые компании в случае открытия хорошего месторождения не только компенсируют понесенные затраты, но и получат существенную прибыль. Важно, что государство 
при этом полностью контролирует скорость и условия оборота участков недр, не допуская их простоя.

Реализация предложенного плана привлечения в геологоразведку частных инвесторов будет способствовать решению главной задачи - увеличению прироста запасов нефти за счет открытия новых месторождений. Кроме того, имеется целый ряд положительных косвенных эффектов. В частности, за счет просчитываемых размеров доказанных открытых запасов и их рентабельности, появляется основа для повышения капитализации независимых поисковых компаний уже в процессе пятилетнего периода проведения ГРР. Этот факт, несомненно, будет способствовать привлечению в отрасль новых инвесторов. Возрастание количества венчурных компаний в лице НГРК приведет к увеличению заказов на сейсморазведочные работы и глубокое бурение, поскольку их собственники объективно должны быть заинтересованы в повышении культуры производства и научно-техническом сопровождении геологоразведочных работ.

Вопросы, как обеспечить скорейшее выставление на аукционные торги открытых месторождений и как должны распределяться средства от их продажи между собственником недр и НГРК, являются предметом отдельного исследования и выходят за рамки данной статьи. Тем не менее, на наш взгляд, следует обозначить ряд базовых принципов, которые должны быть соблюдены:

- государство как собственник недр должно получить обязательную долю от продажи лота на аукционных торгах;

- стартовая стоимость лота должна основываться на методике расчета минимального размера разового платежа за пользование недрами, утвержденную приказом МПР России от 30.09.2008 № 232 со всеми изменениями и дополнениями к ней;

- в случае превышения совокупных затрат на ГРР над расчетной стоимостью лота независимая компания не имеет права отказаться от торгов и не может вернуть себе возможность переоформления лицензии на разведку и добычу.

Изложенные предложения к распорядителю недр по привлечению частных инвесторов к реализации геологоразведочных проектов, на наш взгляд, необходимы, но, конечно, не достаточны. В частности, очень важный аспект успешного привлечения 
инвестиций - появление внешнего контроля (аудита) проектов ГРР в лице независимых консалтинговых компаний, способных просчитать потенциальные риски и прибыльность проектов. Решающим фактором успеха должен быть баланс между величиной понесенных затрат и возможной рыночной стоимостью открытых запасов. Ради осознания этого балансира независимый инвестор объективно будет заинтересован в привлечении квалифицированной независимой экспертизы.

По нашему мнению, предложенный механизм частно-государственного партнерства в конечном итоге приведет к формированию в отрасли новой бизнес-среды, которая, в свою очередь, будет способствовать не просто воспроизводству запасов и компенсации падения добычи нефти в стране, но и появлению творческих, креативно мыслящих профессиональных команд, способных управлять геологоразведочным процессом в течение всего времени существования нефтепоискового проекта.

Статья поступила 05.07.2018.

\section{Summary}

Sokolov A. V., Petrogeco, Nihznevartovsk

The Way to Attract Investment in the Oil Exploration Activities

The article focuses on the urgent problem of attracting the private investment to oil explorations. The author having long-term CEO experience in exploration company examines the potential increase of investigation activity for the three main groups on the national subsoil usage market - government, large vertically integrated corporations and independent exploration companies. As he suppose the independent companies have the greatest potential to increase search activity, but the current regulating arrangements relating the restoration of the mineral resources does not contribute to the investment attractiveness of prospecting. The article proposes some specific measures to motivate the independent investors and attract venture capital in oil exploration.

Restoration of the mineral and raw materials base; explorations work subsoil; oil reserves; oil exploration; geological exploration 